\title{
Embryonic Regulation of Histone Ubiquitination in the Sea Urchin
}

\author{
NIJOLE JASINSKIENE, ALGIMANTAS JASINSKAS, AND JOHN P. LANGMORE \\ Biophysics Research Division and Department of Biology, University of Michigan, Ann Arbor
}

\begin{abstract}
We have used quantitative 2-D protein electrophoresis and immunoprecipitation to study the patterns of histone ubiquitination at $10 \mathrm{~h}$ and $36 \mathrm{~h}$ of embryonic development in Strongylocentrotus purpuratus. Variants $\mathrm{CsH} 2 \mathrm{~A}$, $\alpha \mathrm{H} 2 \mathrm{~A}, \beta \mathrm{H} 2 \mathrm{~A}, \gamma \mathrm{H} 2 \mathrm{~A}, \delta \mathrm{HA}, \mathrm{H} 2 \mathrm{AF} . / \mathrm{Z}, \alpha \mathrm{H} 2 \mathrm{~B}, \beta \mathrm{H} 2 \mathrm{~B}$, and $\gamma \mathrm{H} 2 \mathrm{~B}$ showed up to sevenfold differences in level of monoubiquitination between variants, and individual variants showed up to sixfold changes during development. At $36 \mathrm{~h}$ of embryogenesis, the late variants were less ubiquitinated than the early variants, although the overall level of ubiquitination was appreciably greater than at $10 \mathrm{~h}$. Antiubiquitin antibodies were used to precipitate formaldehydefixed chromatin fragments in order to estimate the degree of ubiquitination of the early histone genes. The $5^{\prime}$ regulatory region of the active $\mathrm{H} 3$ gene appeared to be at least twice as ubiquitinated as the adjacent upstream spacer. However, the absolute level of ubiquitination of the early histone gene repeat seemed to be independent of transcriptional activity. These results show that variant-specific ubiquitination of histones is a part of the developmental program in sea urchin embryos, but is not clearly correlated with transcriptional activity of the early histone genes, except perhaps in the regulatory regions. (c) 1995 Wiley-Liss, Inc.
\end{abstract}

Key words: Histone variants, gene expression, histone ubiquitination, $\mathrm{H} 2 \mathrm{~A}, \mathrm{H} 2 \mathrm{~B}, \mathrm{H} 3$, sea urchin, embryogenesis

\section{INTRODUCTION}

Embryogenesis involves a programmed expression of different genes. Many embryonic transcription factors are inherited from the egg, and it can be surmised that the programming of genes does not occur exclusively by synthesis of new transcription factors, but also by modulation in the activity of pre-existing factors. The activities of the transcription factors could be modulated by post-translational modification of factors themselves and/or modification of the histones associated with specific genes.

Histones are ubiquitous eukaryotic chromosomal proteins that organize DNA into subunits called nucle- osomes. Nucleosomes are composed of an octamer core including two each of histones $\mathrm{H} 2 \mathrm{~A}, \mathrm{H} 2 \mathrm{~B}, \mathrm{H} 3$, and $\mathrm{H} 4$, $146 \mathrm{bp}$ of DNA wrapped around the octamer, and a variable amount of spacer linker DNA that is associated with a fifth histone, H1 [van Holde, 1989]. Despite early evidence that histones played the non-specific roles of condensation of DNA and occlusion of regulatory sequences, it is becoming clear that the activity of specific genes can be dramatically affected by changes in histone amino acid sequence and in nucleosome positioning [Simpson, 1990; Grunstein, 1990; Johnson et al., 1992b; Mann and Grunstein, 1992; Roth et al., 1992]. Histones H2A, H2B, and H3 exist in multiple forms that differ slightly in their primary amino acid sequences [e.g., Franklin and Zweidler, 1977; Wu et al., 1986; van Holde, 1989]. The roles of these histone variants and their postsynthetically modified forms are unknown.

Sea urchin early embryogenesis offers a unique system for study of the function of the histone variants, because within the first $20 \mathrm{~h}$ of development up to five variants are expressed, including cs cleavage stage variants, $\alpha$ early variants, and $\beta, \gamma, \delta$ late histone variants. In addition, rare variants such as $\mathrm{H} 2 \mathrm{AF} . \mathrm{Z}$ are present during embryogenesis and are thought to be correlated with transcriptional activity [Allis et al., 1980; Ernst et al., 1987; Van Daal and Elgin, 1992]. Early histone gene transcriptional activity starts to increase by the 16-cell stage, peaks during early blastula, and then gradually declines to a very low level at the late blastula stage [Maxson and Wilt, 1981; Weinberg et al., 1983]. While early histone variants are synthesized at the early blastula stage when rapid cell division takes place, late histone synthesis is predominant at gastrula stage after primary cell differentiation has occurred [Cohen et al., 1973, 1975; Newrock et al., 1977, 1978; Childs et al., 1979]. Switching from early to late

Received for publication June 20, 1994; accepted January 3, 1995.

Address reprint requests to John P. Langmore, Biophysics Research Division, University of Michigan, 930 North University, Ann Arbor, MI 48109-1055.

Nijole Jansinskiene and Aligimantas Jasinskas are now permanently at the Institute of Biochemistry of the Academy of Sciences of Lithuania, Mokslininky 12, 2600 Vilnius, Lithuania. 
histone variants coincides with dramatic slowing of cell division, with changes in the repertoire of gene expression and alterations in chromatin structure and its transcriptional activity [Arceci and Gross, 1980]. Investigations of the chromatin structure of the sea urchin early histone gene repeat (SUEHGR) have shown DNase I-hypersensitive sites at $10 \mathrm{~h}$ of development, when the genes are transcriptionally active, and a lack of DNase I hypersensitivity at $36 \mathrm{~h}$, when the genes are not active [Bryan et al., 1983; Wu and Simpson, 1985; Fronk et al., 1990].

Histone variants participate in post-translational modifications such as phosphorylation, poly-ADP ribosylation, methylation, acetylation, and ubiquitination [van Holde, 1989]. Histone variants and modifications collectively generate considerable complexity of histone octamers of the nucleosomes that might play a significant role in gene structure and function.

Ubiquitination of non-nuclear proteins is involved with protein degradation and seems to affect DNA repair, cell cycle control, stress response, and cell commitment to death [Hershko, 1988; Jentsch et al., 1990]. Coupling of ubiquitin to proteins is catalyzed by a family of ubiquitin-conjugating enzymes [Jentsch et al., 1990; McGrath et al., 1991] and results in an isopeptide bond between C-terminal glycine residue of ubiquitin and $\varepsilon$-amino group of lysine residue in an acceptor protein [Goldknopt and Busch, 1977; Thorne et al., 1987; Nickel and Davie, 1989]. Multiple ubiquitin groups are a degradation signal for short-lived proteins [Hershko, 1991; Finley and Chau, 1991; Johnson et al., 1992a].

The significance of histone ubiquitination in cell nuclei is not understood although several possibilities exist [Finley and Chau, 1991]. Ubiquitination does not seem to signal degradation of chromosomal proteins, because histones turn over slowly. For instance, in sea urchin the early histone variants are found even in the late developmental stages and in adult tissues [Poccia and Hinegardner, 1975; Newrock et al., 1977; Pehrson and Cohen, 1985; Lieber et al., 1986]. Although the addition of ubiquitin to the C-terminal tails of slightly lysine-rich histones has little effect on the structure of nucleosome core particles [Kleinschmidt and Martinson, 1981], it might prevent the formation of some type of higher-order structure. It was shown that metaphase chromosomes do not contain ubiquitinated histones, and that they are reubiquitinated in anaphase when chromosome decondensation occurs [Matsui et al., 1979; Wu et al., 1981; Mueller et al., 1985]. It was proposed that deubiquitination is a general factor in chromosome condensation [Matsui et al., 1979], or this modification could label specific chromatin regions containing the expressed genes or a subset of these genes required by the cell to be available for activation [Mueller et al., 1985]. Alternatively, ubiquitination of histones might occur as a consequence of transcriptional activity, perhaps related to an apparent increase in histone $\mathrm{H} 2 \mathrm{~A}$ and $\mathrm{H} 2 \mathrm{~B}$ exchange during transcription [Schwager et al., 1985].

In certain cases histone ubiquitination is correlated with transcriptional activity, but the generality of this result and the role of ubiquitination in gene regulation are not certain.

One method to study the ubiquitination of specific nucleosomes is to perform nucleoprotein gel electrophoretic analysis on nucleosome core particles produced by micrococcal nuclease digestion of nuclei and extensive formaldehyde fixation [Levinger and Varshavsky, 1982]. Ubiquitinated core particles electrophorese more slowly than non-ubiquitinated particles. Transfer of DNA from the nucleoprotein gel to a filter followed by hybridization with specific DNA probes was used to test whether the nucleosome core particles bound to active and inactive genes had migrated normally or were retarded. Using this assay it was concluded that ubiquitinated histones were located in transcribed genes in Drosophila melanogaster [Levinger and Varshavsky, 1982] and on active mouse dihydrofolate reductase genes [Barsoum and Varshavsky, 1985]. In contrast, using similar techniques, Huang et al. [1986] concluded that active immunoglobulin $k$ chain genes were packaged by non-ubiquitinated histones, because although the active genes were retarded on nucleoprotein gels, the retardation could not be prevented by deubiquitination of the samples. Therefore in some cases a different modification or protein (perhaps histone H2A.X) can be present on the active nucleosomes that causes core particles to comigrate with ubiquitinated core particles [Huang et al., 1986].

Using a different approach Ridsdale and Davie [1987] reported that chicken erythrocyte polynucleosomes that were enriched in active $\beta$-globin DNA sequences were also enriched in ubiquitinated $\mathrm{H} 2 \mathrm{~A}$ and H2B. Nickel et al. [1989] showed that bovine thymus and chicken erythrocyte chromatin enriched in active gene sequences was also enriched in mono and polyubiquitinated species of histones $\mathrm{H} 2 \mathrm{~A}, \mathrm{H} 2 \mathrm{~B}$, and H2A.Z. Davie and Murphy [1990] found that Tetrahymena $\mathrm{H} 2 \mathrm{~A}$ and $\mathrm{H} 2 \mathrm{~B}$ were more highly ubiquitinated in macronuclei, which are transcriptionally active, than in the micronuclei, which are not active. They proposed that ubiquitination of histone H2B may promote nucleosome unfolding to facilitate transcription. However, analysis of $\mathrm{H} 2 \mathrm{~A}$ substitution mutations in yeast argues against a requirement for histone ubiquitination [Swerdlow et al., 1990], and the studies of Davie and collaborators cannot exclude the possibility that ubiquitinated histones are not directly associated with active genes but coincidentally coisolated in the fractions that are enriched in active genes.

Thus there are three interesting questions about histone ubiquitination during development. First, is ubiquitination of bulk histones correlated with development? Second, are the different variants of $\mathrm{H} 2 \mathrm{~A}$ and H2B differentially ubiquitinated, indicating a specific- 
ity to the process, or are all variants equally modified, indicating non-specificity? Third, is ubiquitination of the histones associated with a specific gene correlated with transcriptional activity of that gene? In this paper we examined the level of ubiquitination of each histone variant from two stages of sea urchin early development, early blastula and gastrula, when significant changes in chromatin structure and function occur. The results are the first report of ubiquitination in sea urchin and the first demonstration that a program of specific ubiquitination and deubiquitination accompanies embryonic development. In addition, immunoprecipitation with antiubiquitin antibodies was used to investigate ubiquitination of active (10-h embryos) and non-active (36-h embryos) early histone genes. In the region of the early histone $\mathrm{H3}$ gene, the promoter sequences were more highly ubiquitinated than the coding sequences, and the coding sequences were more highly ubiquitinated than the 5 ' spacer region. However, the absolute level of ubiquitination of the entire early histone repeat seems independent of the level of transcriptional activity.

\section{MATERIALS AND METHODS \\ Sea Urchin Embryo Cultures and Nuclear Isolation}

The nuclei were isolated from Strongylocentrotus purpuratus embryos as described by Vincenz et al. [1991], except all solutions included $10 \mathrm{mM}$ butyrate. Embryos were grown continuously in the presence of either $\left[4,5-{ }^{3} \mathrm{H}\right]$ lysine or $\left[\right.$ methyl $\left.-{ }^{3} \mathrm{H}\right]$ thymidine $(1 \mu \mathrm{Ci} /$ ml, Amersham: Arlington Heights, IL). Typical specific activities were $2 \times 10^{4} \mathrm{cpm} / \mu \mathrm{g}$ for protein or $10^{5}$ $\mathrm{cpm} / \mu \mathrm{g}$ for DNA, assuming that $A_{260}$ was 20 for a 1 $\mathrm{mg} / \mathrm{ml}$ solution of DNA and a protein:DNA ratio of 1 for chromatin. Protein and DNA concentrations were determined by radioactive counts. The nuclei were stored at a concentration of $1 \mathrm{mg} / \mathrm{ml}$ in buffer $A(15 \mathrm{mM}$ HEPES pH 7.3, $60 \mathrm{mM} \mathrm{KCl}, 15 \mathrm{mM} \mathrm{NaCl}, 1 \mathrm{mM}$ ethylenediamine tetraacetic acid [EDTA], $0.5 \mathrm{mM}$ spermidine, $0.15 \mathrm{mM}$ spermine, $0.1 \mathrm{mM}$ phenylmethylsulfonyl fluoride [PMSF], $5 \mathrm{mM}$ iodoacetate, $6 \mu \mathrm{M}$ leupeptin, $10 \mathrm{mM}$ sodium butyrate) containing $50 \%$ glycerol. The nuclei were rapidly frozen in a dry ice/ methanol bath and stored at $-80^{\circ} \mathrm{C}$ for up to 1 year.

\section{Preparation of Sea Urchin Histones and Two-Dimensional Electrophoresis}

In a typical preparation nuclei were thawed on ice and centrifuged at $16,000 \mathrm{~g}$ for $10 \mathrm{~min}, 0.4 \mathrm{NH}_{2} \mathrm{SO}_{4}$ was added to the pellet, and the mixture was shaken overnight at $4^{\circ} \mathrm{C}$ and centrifuged at $16,000 \mathrm{~g}$ for $30 \mathrm{~min}$. The pellet was extracted for $2 \mathrm{~h}$, both supernatants were combined, and proteins were precipitated with 5 volumes of ethanol at $-20^{\circ} \mathrm{C}$ for $2 \mathrm{~h}$.

The two-dimensional electrophoresis of histone was performed in a $15 \%$ polyacrylamide slab gel. The first dimension was an acid urea triton (AUT) gel $(0.9 \mathrm{M}$ acetic acid, $8 \mathrm{M}$ urea, and $6 \mathrm{mM}$ Triton X-100) [Zweidler, 1978]. The second dimension was an acid urea (AU) gel (0.9 M acetic acid and 2.3 $\mathrm{M}$ urea) [Panyim and Chalkley, 1969]. Sodium dodecyl sulfate (SDS) gels were run according to Laemmli [1970]. Proteins were stained with Coomassie BB G-250 (Serva Biochemicals: Paramus, NJ).

\section{Transfer of Histones and Immunochemical Detection of Ubiquitinated Histone Species}

Two-dimensional polyacrylamide gel electrophoresis (acid urea Triton [AUT] into acid urea [AU]) was used to resolve histone proteins and their variants. The proteins were electrophoretically transferred by using a modified technique of Delcuve and Davie [1992]. The best separations were achieved using AUT in the first dimension and $\mathrm{AU}$ in the second dimension. This gives good resolution of $\mathrm{H} 2 \mathrm{~A}$ variants and separates their ubiquitinated species from nonhistone nuclear proteins. In this case $\gamma$ and $\delta$ late $H 2 A$ variants were better separated from early variants than with AUT/SDS. Better separation of $\mathrm{H} 2 \mathrm{~B}$ early and late variants was also achieved in the AUT/AU system. AU gels were washed 2 times for $30 \mathrm{~min}$ in $100 \mathrm{ml}$ of $50 \mathrm{mM}$ acetic acid, $0.5 \%$ SDS and for $30 \mathrm{~min}$ in $100 \mathrm{ml}$ of $5 \% \beta$-mercaptoethanol, $2.3 \% \mathrm{SDS}$, and $62.5 \mathrm{mM}$ Tris- $\mathrm{HCl}, \mathrm{pH}$ 6.8. SDS gels were washed $2 \times 30 \mathrm{~min}$ in transfer buffer (25 mM CAPS, pH 10, and $20 \%$ [v/v] methanol). Transfer to nitrocellulose membranes (TM-NC Hoefer Scientific Instruments: San Francisco, CA) were performed in the transfer buffer with Bio Rad Trans-Blot apparatus ( $70 \mathrm{~V}$ for $2 \mathrm{~h}$ ) with cooling at $4^{\circ} \mathrm{C}$. The filters were soaked in $100 \mathrm{ml}$ TBS buffer $(500 \mathrm{mM} \mathrm{NaCl}, 50$ $\mathrm{mM}$ Tris- $\mathrm{HCl}, \mathrm{pH} 8.0$ ) for $4 \times 15 \mathrm{~min}$ at room temperature, air-dried, and autoclaved or used directly. Filters were autoclaved $30 \mathrm{~min}$ at $120^{\circ} \mathrm{C}$ between two sheets of $3 \mathrm{MM}$ paper covered by deionized water [Swerdlow et al., 1986]. The water was removed, and the filters were left in the autoclave for the dry cycle. The filters were rehydrated with TBS for $1 \times 5 \mathrm{~min}$ at room temperature, treated with blocking solution (10\% BSA in TBS) for $1 \mathrm{~h}$, and washed $2 \times 15 \mathrm{~min}$ with TTBS (500 mM NaCl, $50 \mathrm{mM}$ Tris- $\mathrm{HCl}$, pH 8.0, 0.1\% Tween-20). Anti-ubiquitin polyclonal antibodies from J.R. Davie (or Sigma: St Louis, MO) were diluted $1: 1,000$ (or $1: 10$ ) with antibody dilution buffer (1\% BSA $\mathrm{n}$ TBS), added to the nitrocellulose filters $\left(0.1 \mathrm{ml} / \mathrm{cm}^{2}\right)$ in a roller oven (Red Roller, Hoefer), and incubated $3 \mathrm{~h}$ at room temperature. The filters were washed $3 \times 15$ min with TTBS, and incubated $1 \mathrm{~h}$ in antibody dilution buffer containing $2 \times 10^{5} \mathrm{dpm} / \mathrm{ml}\left[{ }^{125} \mathrm{I}\right]$ protein A (Amersham, specific activity $30 \mathrm{mCi} / \mathrm{mg}$ ). Nonspecifically bound $\left[{ }^{125} \mathrm{I}\right]$ protein A was removed with TTBS for $3 \times 15 \mathrm{~min}$ at room temperature. Filters were air-dried and exposed to X-OMAT AR film (Kodak: Rochester, NY). 


\section{Chromatin Fixation and Sonication}

The nuclei (typically $50 \mu \mathrm{g}$ in $100 \mu \mathrm{l}$ ) were centrifuged at $2,200 \mathrm{~g}$ for $5 \mathrm{~min}$ and resuspended in $200 \mu \mathrm{l}$ fixation buffer ( $20 \%$ glycerol, $125 \mathrm{mM} \mathrm{KCl}, 0.15 \mathrm{mM}$ Na-EDTA, $2.5 \mathrm{mM}$ DTT, and $25 \mathrm{mM}$ Na-HEPES, $\mathrm{pH}$ 7.5). Formaldehyde was added to $1 \%$ for $3 \mathrm{~min}, 10 \mathrm{~min}$, $30 \mathrm{~min}$, and $60 \mathrm{~min}$ at room temperature. Fixation was stopped by pelleting the nuclei at $2,200 \mathrm{~g}$ for $30 \mathrm{~s}$ and resuspending in an equal volume of ice-cold PBS (10 $\mathrm{mM} \mathrm{NaH} \mathrm{PO}_{4}, 150 \mathrm{mM} \mathrm{NaCl}, \mathrm{pH}$ 7.4). The nuclei were quickly pelleted again and washed for $10 \mathrm{~min}$ at $4^{\circ} \mathrm{C}$ in each of the following 200- $\mu$ l solutions: phosphate-buffered saline (PBS); $0.25 \%$ Triton X-100, $10 \mathrm{mM} \mathrm{Na-}$ EDTA, $0.5 \mathrm{mM}$ Na-EGTA, $10 \mathrm{mM}$ Na-HEPES, pH 6.5; and $200 \mathrm{mM} \mathrm{NaCl}, 1 \mathrm{mM}$ Na-EDTA, $0.5 \mathrm{mM}$ NaEGTA, $10 \mathrm{mM}$ Na-HEPES, $\mathrm{pH}$ 6.5. The nuclei were resuspended in $200 \mu \mathrm{l}$ SDS buffer (2\% SDS, $10 \mathrm{mM}$ Na-EDTA, $50 \mathrm{mM}$ Tris $\mathrm{HCl}, \mathrm{pH} 8.1,1 \mathrm{mM}$ PMSF, and leupeptin $6 \mu \mathrm{M}$ ) and were sonicated with the Branson Model 185 sonifier micro tip (Branson Ultrasonics: Danbury, CT) at power setting 5 for three 10 -s bursts separated by cooling on ice. This treatment reduced the mean DNA size to $\sim 0.6 \mathrm{~kb}$ (data not shown). The sonicate was centrifuged at $16,000 \mathrm{~g}$ for $3 \mathrm{~min}$. The supernatant was diluted 20 -fold with dilution buffer ( $1 \%$ Triton X-100, $2 \mathrm{mM} \mathrm{Na-EDTA}, 150 \mathrm{mM} \mathrm{NaCl}, 20 \mathrm{mM}$ Tris, $\mathrm{pH}$ 8.1) supplemented with protease inhibitors.

\section{Immunoprecipitation}

Samples of fixed chromatin fragments containing 0.5 $\mu \mathrm{g}$ DNA (based on [methyl ${ }^{3} \mathrm{H}$ ] thymidine radioactivity) were diluted with $0.1 \%$ SDS, $1 \%$ Triton X-100, 2 $\mathrm{mM}$ Na-EDTA, $500 \mathrm{mM} \mathrm{NaCl}, 20 \mathrm{mM}$ Tris, $\mathrm{pH} 8.1$ to a final volume of $200 \mu \mathrm{l}$. Immune serum $(20 \mu \mathrm{l})$ was added with protease inhibitors and incubated on a rocker platform for $24 \mathrm{~h}$ at $4^{\circ} \mathrm{C}$. Twenty-microliters of $50 \%(\mathrm{v} / \mathrm{v})$ protein A-Sepharose (Pharmacia) suspension was added, and incubation was continued for $3 \mathrm{~h}$ at $4^{\circ} \mathrm{C}$. The beads were centrifuged at $16,000 \mathrm{~g}$ for $15 \mathrm{~s}$, the supernatant (unbound fraction) was saved, and beads were washed with gentle agitation for $5 \mathrm{~min}$ at $4^{\circ} \mathrm{C}$ in $1 \mathrm{ml}$ of each of the following buffers: twice with $0.1 \%$ SDS, $1 \%$ Triton X-100, $2 \mathrm{mM} \mathrm{Na-EDTA,} 500 \mathrm{mM} \mathrm{NaCl}$, $20 \mathrm{mM}$ Tris, $\mathrm{pH} 8.1$, and once with $0.25 \mathrm{M} \mathrm{LiCl}, 1 \%$ Nonidet P-40, $1 \%$ deoxycholate, $1 \mathrm{mM}$ Na-EDTA, 10 $\mathrm{mM}$ Tris, $\mathrm{pH}$ 8.1. After two final washes in TE the immune complexes were eluted from the protein A-Sepharose with several washings of $1 \%$ SDS, 100 $\mathrm{mM} \mathrm{NaHCO}{ }_{3}$. Formaldehyde crosslinks were reversed at $65^{\circ} \mathrm{C}$ for $6 \mathrm{~h}$, and DNA was purified by incubation with $0.5 \mathrm{mg} / \mathrm{ml}$ proteinase $\mathrm{K}, 0.1 \% \mathrm{SDS}$, for $2 \mathrm{~h}$ at $37^{\circ} \mathrm{C}$. The DNA was precipitated by adding $2 \mathrm{M}$ ammonium acetate, $5 \mu \mathrm{g} / \mathrm{ml}$ tRNA, and 2 volumes of ethanol. Protein was precipitated in $30 \%$ trichloroacetic acid at $4^{\circ} \mathrm{C}$ overnight, centrifuged at $16,000 \mathrm{~g} 30 \mathrm{~min}$, and washed once with $0.1 \% \mathrm{HCl}$ in acetone and twice with acetone at $4^{\circ} \mathrm{C}$. The pellet was dried and resuspended in SDS probe buffer $(0.06 \mathrm{M}$ Tris, $\mathrm{pH} 6.8,12 \%$ glycerol, $2 \%$ glycerol, $2 \%$ SDS, $5 \%$ ß-mercaptoethanol). The proteins were extracted with $0.4 \mathrm{~N}$ sulfuric acid at $4^{\circ} \mathrm{C}$ overnight with vigorous shaking and precipitated with 5 volumes of ethanol.

For the competition experiments, competitor was dissolved in SDS buffer by boiling $1 \mathrm{~min}$ and was diluted 20 -fold with $0.1 \%$ SDS, $1 \%$ Triton X-100, 2 mM NaEDTA, $500 \mathrm{mM} \mathrm{NaCl}, 20 \mathrm{mM}$ Tris- $\mathrm{HCl}, \mathrm{pH}$ 8.1. Varying quantities of competing protein were added to the immunoprecipitation reaction mixture, containing $0.5 \mathrm{mg}$ DNA and $20 \mu l$ antiubiquitin. In control experiments nonimmune serum (Flow Labs: McLean, VA) was used.

\section{DNA Dot Blotting and Quantitation of Autoradiograms}

DNA dot blotting and hybridization were made as in Vincenz et al. [1991] using random primer labeling (Gibco BRL: Gaithersburg, MD). Rehybridization washes were at $42^{\circ} \mathrm{C}$ with $0.4 \mathrm{~N} \mathrm{NaOH}$ for $30 \mathrm{~min}$, followed by $2 \times 15 \mathrm{~min}$ in $0.1 \times \mathrm{SSC}, 0.1 \%$ SDS, $0.2 \mathrm{M}$ Tris, $\mathrm{pH}$ 7.5. Quantitation of autoradiograms was performed using a cooled CCD (Star 1, Photometrics: Tucson, AZ). The images were converted to optical densities on a Silicon Graphics INDIGO (Mountain View, CA). The specific activities of different histone variants were assumed to be proportional to the number of lysine residues. Protein spot intensities were calculated using EMPRO image processing package. X-ray films were exposed for different times to achieve linearity of response. Quantitation of the DNA dot blots were done similarly. The linearity of response was checked using a dilution series of purified sea urchin sperm DNA.

\section{DNA Probes}

DNA fragments used as radioactive probes for hybridization were derived from the complete SUEHGR clone, pCO2 A [Overton and Weinberg, 1978]. Plasmid DNA was cut to completion with restriction endonucleases and electrophoresed in preparative low melting $1 \%$ agarose gels. Restriction enzymes, EcoRI, XbaI, HindIII were from Boehringer Mannheim, and XhaI was from Gibco BRL. Appropriate bands were cut out and purified by ion-exchange chromatography (Elutip, Schleicher and Schuell: Keene, NH). Probes were labeled with $5^{\prime}-\left[\alpha{ }^{32} \mathrm{P}\right] \mathrm{CTP}$ (Amersham) using a randomprimer kit (Gibco BRL) to $\sim 1-5 \times 10^{8} \mathrm{dpm} / \mu \mathrm{g}$.

\section{Estimation of the Absolute Level of Ubiquitination}

We would like to relate enrichment (or depletion) of a particular sequence in the immunoprecipitated fraction to the degree of ubiquitination of the histones bound to that sequence. However, there are several immeasurable and potentially uncontrolled variables that might vary among different preparations, embryonic stages, and even specific genes. The data analysis must recognize which variables are probably constant 
and which not, and eliminate dependence of the results upon those variables most likely to change. With this goal in mind, we have focused our analysis on the experimentally determined parameter $F$, which is the fraction of the DNA immunoprecipitated. $F$ can be determined for embryos at different times of development, $t$, and for specific or bulk sequences (denoted $F(s, t)$ or $F(b, t))$, respectively. $F(s, t)$ is simply the fraction of a specific gene that is immunoprecipitated (measured by dot-blot hybridization), $F(b, t)$ is simply the fraction of the bulk DNA that is immunoprecipitated (measured by scintillation counting tritiated thymidine). The ratio $F(s, t) / F(b, t)$ is the enrichment, $E(s, t)$, of a specific gene. The variable $E(s, t)$ will be used to estimate differences in the extent of ubiquitination in different parts of the same genome and to compare the extent of hybridization of the same genes at different times of embryogenesis. The amount of DNA that is non-specifically precipitated also affects $F$, but will be ignored due to the low background precipitation of both bulk and specific genes $(\sim 15 \%), F$ can be written as a product:

$$
F=\varepsilon_{p} \cdot \varepsilon_{f} \cdot f_{u} \cdot n \cdot N, \text { where }
$$

$$
\begin{aligned}
N= & \text { the average molecular weight of the DNA frag- } \\
& \text { ments (bp) } \\
n= & \text { the average number of histone H2A and H2B } \\
& \text { molecules per bp } \\
f_{u}= & \text { the fraction of histone H2A and H2B molecules } \\
& \text { that are ubiquitinated } \\
\varepsilon_{f}= & \text { the efficiency of fixation of histones to the DNA } \\
\varepsilon_{p}= & \text { the efficiency of immunoprecipitation of fixed, } \\
& \text { ubiquitinated histones }
\end{aligned}
$$

Nominal values for these variables in our study are: $N \approx 600 \mathrm{bp} ; \mathrm{n} \approx 0.019$, because there are four molecules of $\mathrm{H} 2 \mathrm{~A}$ and $\mathrm{H} 2 \mathrm{~B}$ per nucleosome and one nucleosome every $213 \mathrm{bp} ; f_{u} \approx 0.01-0.04$ (this study); $\varepsilon_{f} \approx$ 0.8 (data from Coomassie-stained SDS gels of fixed chromatin, not shown); and $\varepsilon_{p} \approx 1$ (this study). Substituting these nominal values for the variables in the equation for $F$, we predict a nominal value of $F \approx 0.09$ 0.36 , consistent with our observations of bulk chromatin (this study). For the equation for $F$ to be valid the number of ubiquitinated histones fixed to the DNA, $\varepsilon_{f} \cdot f_{u} \cdot n \cdot N$, should be less than 0.5 , which means that $F \leq 0.5$, which was always the case in our experiments. $F$ is not useful by itself, because it is sensitive to a number of variables that are difficult to control from experiment to experiment $\left(\varepsilon_{p}, \varepsilon_{f}\right.$, and $\left.N\right)$. The ratio of $F$ 's for a particular immunoprecipitation is more useful, because the dependence upon many of these variables can be reduced or eliminated. $E(s, t)$ is given by the equation

$$
E(s, t)=\frac{F(s, t)}{F(b, t)}=\frac{f_{u}(s, t)}{f_{u}(b, t)} \cdot\left(\frac{\varepsilon_{p}(s, t)}{\varepsilon_{p}(b, t)} \cdot \frac{\varepsilon_{f}(s, t)}{\varepsilon_{f}(b, t)} \cdot \frac{n(s, t)}{n(b, t)} \cdot \frac{N(s, t)}{N(b, t)}\right)
$$

The only way to relate $E(s, t)$ to the extent of ubiquitination is to estimate reasonable values for the terms within the right hand parentheses, which is made easier because they are ratios of values from the same immunoprecipitation. Each quotient is assumed to be 1 :

$$
\begin{aligned}
& \frac{N(s, t)}{N(b, t)}=1 \text {, because all of the sonicated DNA should have the } \\
& \frac{n(s, t)}{n(b, t)} \cong 1 \text {, because there is no evidence that the density of }
\end{aligned}
$$

and we are left with the relationship:

$$
E(s, t) \cong \frac{f_{u}(s, t)}{f_{u}(b, t)}
$$

The absolute extent of ubituitination at time $t$ can be estimated from the equation $f_{u}(s, t) \cong E(s, t) f_{u}(b, t)$, where $f_{u}(b, t)$ can be determined by electrophoresis of the bulk histones.

In order to compare the level of ubiquitination of a specific sequence at 10 and $36 \mathrm{~h}$ of development we can use the ratio

$$
\begin{aligned}
& \frac{E(s, 10)}{E(s, 36)} \cong\left(\frac{f_{u}(s, 10)}{f_{u}(b, 10)}\right)\left(\frac{f_{u}(b, 36)}{f_{u}(s, 36)}\right), \text { which can be arranged to give } \\
& \frac{f_{u}(s, 10)}{f_{u}(s, 36)} \cong\left(\frac{E(s, 10)}{E(s, 36)}\right)\left(\frac{f_{u}(b, 10)}{f_{u}(b, 36)}\right) .
\end{aligned}
$$

\section{RESULTS}

\section{Estimation of Histone Ubiquitination in Two Development Stages}

Ubiquitinated histone species were identified with specific antibodies. Proteins from two-dimensional gels (AUT/AU) were electrophoretically transferred to nitrocellulose membrane and immunochemically stained for ubiquitin with anti-ubiquitin antibodies and $\left[{ }^{125} \mathrm{I}\right]$ labeled protein A. Localization of ubiquitinated histones from 10-h nuclei is shown in Figure 1. Comparison of the autoradiogram and stained gel revealed the position and modified species of histones H2A and H2B and confirmed the specificity and reactivity of the antibodies for ubiquitinated proteins on nitrocellulose. 

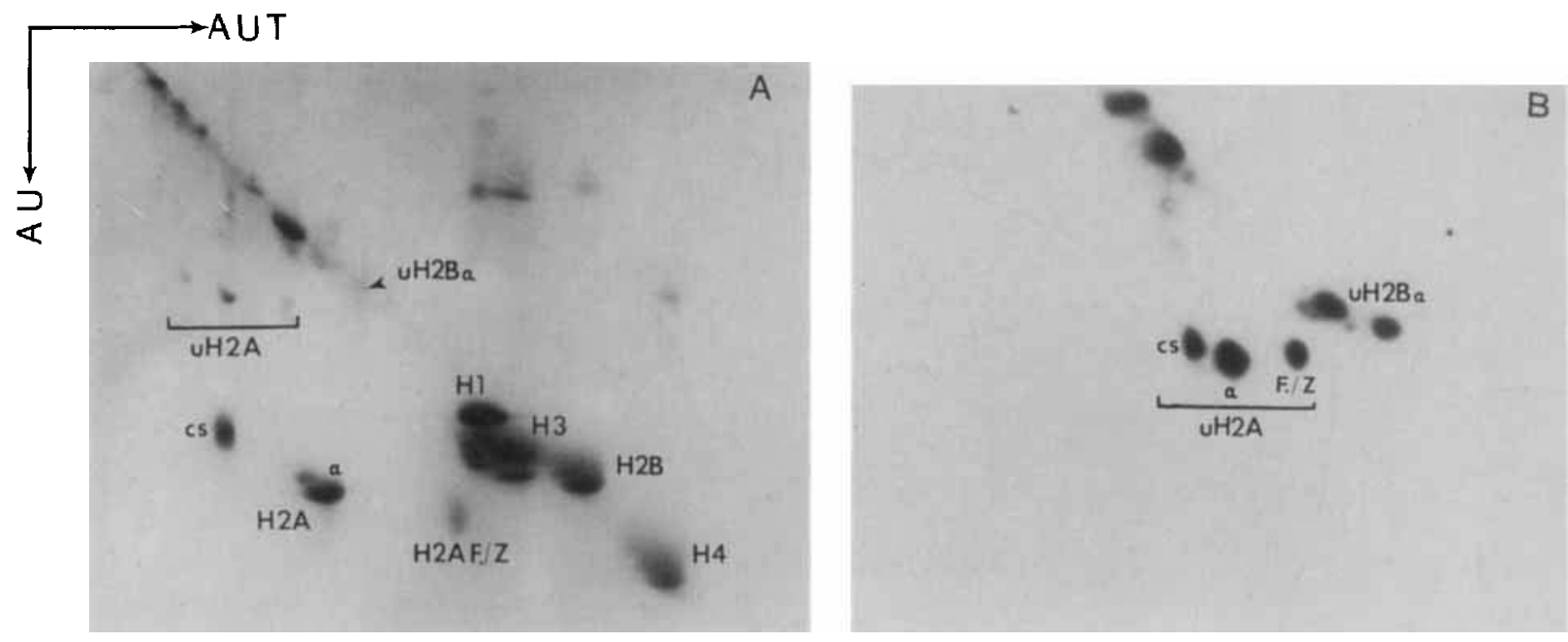

Fig. 1. Identification of ubiquitinated histone variants in AUT/AU gels. A: Two-dimensional electrophoresis of $0.4 \mathrm{~N} \mathrm{H}_{2} \mathrm{SO}_{4}$-soluble nuclear proteins from $10 \mathrm{~h}$ embryos, detected by Coomassie staining. $\mathrm{B}$ : Western blot of the 2-D gel shown in A. The proteins were electrophoretically transferred to nitrocellulose and immunochemically stained with antiubiquitin antibodies and ${ }^{125}$ I-labeled protein A. Ubiquitinated histones species are labeled as uH2A and uH2B.

To estimate the amount of ubiquitinated histones in 10-h and 36-h nuclei, embryos were labeled continuously during development, and the histones were acidextracted, separated by two-dimensional electrophoresis, and quantified by fluorography. The fluorograms of the acid-soluble proteins are shown in Figure 2A,B. The radioactive assays of each of the $\mathrm{H} 2 \mathrm{~A}$ and $\mathrm{H} 2 \mathrm{~B}$ variants and of their ubiquitinated forms are recorded in Table 1. Significant variations were observed among the different histone variants and between the two developmental stages.

The first result is that the level of ubiquitination of each of the variants was in the range $0.6-4.4 \%$. This is comparable to the level of ubiquitination in trout liver [Nickel et al., 1987] and Physarum [Mueller et al., 1985]. In agreement with other systems, which seem to favor ubiquitination of H2A [West and Bonner, 1980; Bush and Goldknopf, 1981], 10-h embryos favor ubiquitination of $\mathrm{H} 2 \mathrm{~A}$ over $\mathrm{H} 2 \mathrm{~B}$. In contrast, 36-h embryos favor ubiquitination of $\mathrm{H} 2 \mathrm{~B}$ over H2A. Also in contrast to other systems, diubiquitinated sea urchin histones were not detectable by Coomassie staining, autoradiography, or immunoblotting at either $10 \mathrm{~h}$ or $36 \mathrm{~h}$. The lower limit for autoradiographic detection of diubiquitinated $\alpha \mathrm{H} 2 \mathrm{~A}$ at $36 \mathrm{~h}$ was $\sim 0.03 \%$.

Quantitation of the total amounts of ubiquitinated histones relative to nonubiquitinated histones at the two stages showed about twofold greater ubiquitination at $36 \mathrm{~h}$, which was primarily due to a sixfold increase in the amount of ubiquitinated $\mathrm{H} 2 \mathrm{~B}$ at $36 \mathrm{~h}$. Assuming that two copies of $\mathrm{H} 2 \mathrm{~A}$ and $\mathrm{H} 2 \mathrm{~B}$ are bound to each nucleosome, the calculated average number of ubiquitin moieties per nucleosome is 0.04 ubiquitins per nucleosome at $10 \mathrm{~h}$ and 0.07 ubiquitins per nucleosome at $36 \mathrm{~h}$. Ubiquitination of $\mathrm{H} 2 \mathrm{~A}$ increased only slightly, but ubiquitinated $\alpha H 2 B$ increased more than sixfold. Ubiquitination of H2AF./Z was difficult to quantitate, because of the small amounts present $(5.8 \%$ of total histone H2A at $10 \mathrm{~h}$ and $6.7 \%$ at $36 \mathrm{~h}$ ).

There were considerable differences in the extent of ubiquitination of different variants, ranging from 0.6 to $4.4 \%$. The late variants seem to be ubiquitinated less than the early variants, but $\beta \mathrm{H} 2 \mathrm{~A}$ seemed to be an exception. Thus there is no systematic correlation between the age of the protein and degree of ubiquitination. The total level of ubiquitination of $\mathrm{H} 2 \mathrm{~B}$ was about the same as that of H2A, in contrast to other systems, which are preferentially ubiquitinated at $\mathrm{H} 2 \mathrm{~A}$.

\section{Specificity of Antibodies}

The immunoblotting experiment presented in Figure 1 shows that the antiserum was specific for ubiquitin at $10 \mathrm{~h}$ of development. Figure $3 \mathrm{~A}, \mathrm{~B}$ show that only ubiquitinated variants of histones $\mathrm{H} 2 \mathrm{~A}$ and $\mathrm{H} 2 \mathrm{~B}$ were immunolabeled at $36 \mathrm{H}$ of development. This specificity was achieved when high ionic strength ( $500 \mathrm{mM} \mathrm{NaCl}$ ) was used for the reaction.

The specificity of ubiquitin antiserum was further tested by examining proteins from the immunoprecipitation reaction with 10 -h chromatin. Complexes were decrosslinked, and proteins were precipitated with trichloroacetic acid and separated by SDS polyacrylamide gel electrophoresis (PAGE). Ubiquitinated histones were located between $\mathrm{H} 1$ and $\mathrm{H} 3$, as seen by comparing the Coomassie-stained gel and the immunoblot (Fig. 4, lanes 1-3). After fixation with formaldehyde the immunoprecipitated proteins reacted with antiserum specifically (lanes $4-6$ ). The greatest amount of ubiquitinated proteins were recovered from immunocomplexes 

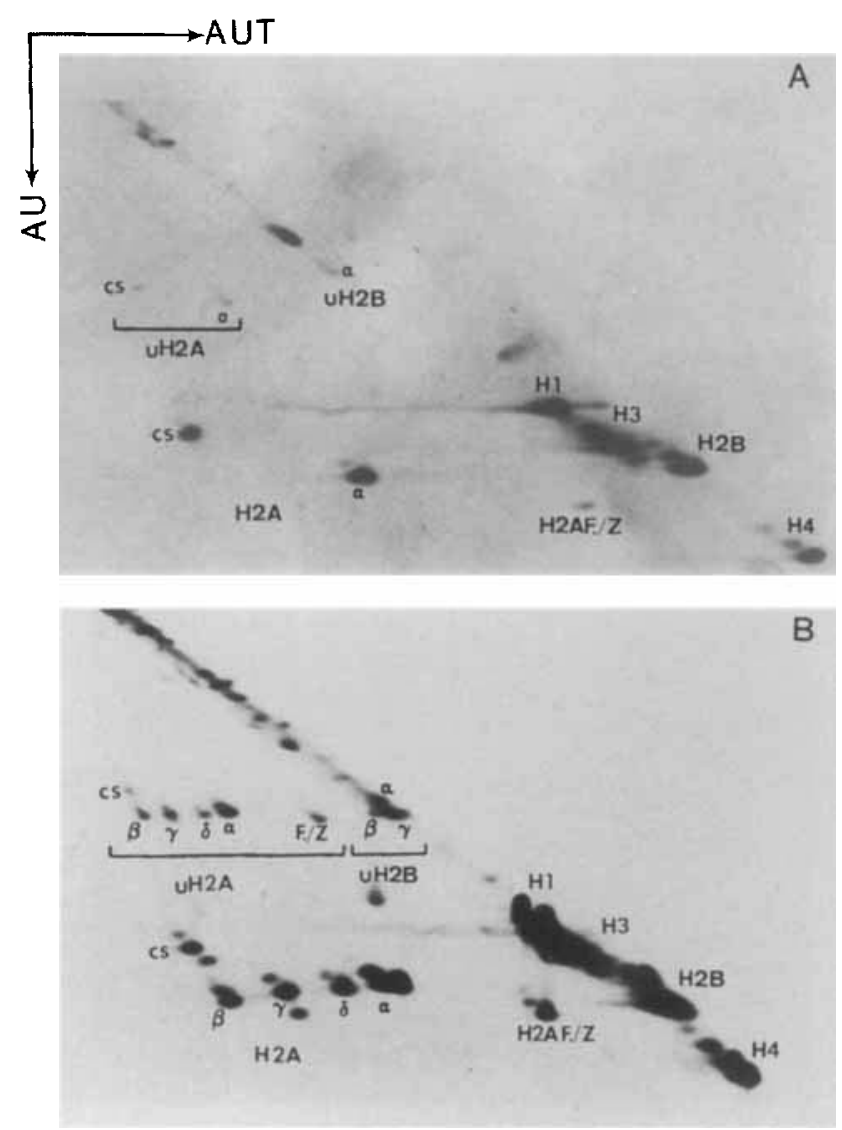

Fig. 2. Estimate of amount of ubiquitinated histone variants in 10 -h and 36-h nuclei. Embryos were labeled in vivo with ${ }^{3} \mathrm{H}$-lysine. $0.4 \mathrm{~N} \mathrm{H}_{2} \mathrm{SO}_{4}$ soluble nuclear proteins were separated by AUT/AU electrophoresis. A: Fluorogram from 10-h nuclei. B: Fluorogram of 36-h nuclei. X-ray films were exposed for different times in order to quantify the fluorograms with the CCD. The ratio of integrated densities for each ubiquitinated and nonubiquitinated species were calculated and converted to percentage ubiquitination as described in Materials and Methods.

after $10 \mathrm{~min}$ of fixation. We conclude that the immunoprecipitation was specific for monoubiquitinated $\mathrm{H} 2 \mathrm{~A}$ and $\mathrm{H} 2 \mathrm{~B}$, with no detectable precipitation caused by other ubiquitinated species. Furthermore, the efficiency of immunoprecipitation seems to be very high, because no ubiquitinated proteins were detected in the immunoreaction supernatant.

Fixation time was important to immunoprecipitation and must be optimized to precipitate the largest amount of chromatin, while retaining specificity [Dedon et al., 1991]. The dependence of immunoprecipitation upon fixation time is presented in Figure 5. The amount of immunoprecipitated complexes from blastula and gastrula reaches maximum after $10 \mathrm{~min}$ of fixation and then declines. Presumably at shorter times there is a shortage of protein bound to the DNA fragments, while at longer times fixation interferes with the ability of the antibodies to bind to the frag- ments. Precipitation of $10-\mathrm{h}$ chromatin fixed for $10 \mathrm{~min}$ using nonimmune serum resulted in sevenfold less precipitation than when using antiubiquitin antibodies.

The specificity of antiserum was also tested by adding different quantities of ubiquitin to compete for the antibody. The results are presented in Figure 6. Added ubiquitin decreased the amount of precipitated complexes about fourfold. This competition was also able to decrease the precipitation of specific genes fourfold (see below), showing similar specificities of the reaction with bulk and specific-gene chromatin.

\section{Investigation of Ubiquitination of Early Histone Genes in Two Development Stages}

To investigate the ubiquitination of histone genes, DNA was isolated from immunoprecipitated complexes from 10- and 36-h embryos and hybridized with DNA probes to SUEHGR. Figure 7 presents the SUEHGR restriction map and the probes used for dot-blot hybridization. pCO2A contains the entire repeat, whereas pSp102 contains one of the two EcoR I fragments. Three smaller probes were isolated to probe sequences in the spacer, promoter, and coding regions of histone H3. Figure 8 shows sample autoradiograms of immunoprecipitated and total genomic DNA probed with $\mathrm{pSp102}$. The blots were quantified from the amount of tritium loaded into each dot from total and immunoprecipitated nucleoprotein, and from the amount of hybridization to the dots. The enrichment for specific sequences, $E(s, t)$, is equal to the ratio of the hybridization signal per $\mu \mathrm{g}$ immunoprecipitated DNA to the hybridization signal per $\mu \mathrm{g}$ total DNA (from the same preparation before immunoprecipitation). The specificity of the immunoprecipitation reaction was confirmed by showing that addition of free ubiquitin could prevent $85 \%$ of the reaction with SUEGHR sequences (data not shown). The results of the immunoprecipitation experiments are summarized in Table 2.

Hybridization with pCO2A showed the level of ubiquitination of the histones bound to the histone genes at the two development stages. At $36 \mathrm{~h}$ of development, the inactive SUEHGR sequences were immunoprecipitated twice as efficiently as bulk sequences. At $10 \mathrm{~h}$ of development, active histone genes were precipitated four times as efficiently. These results were confirmed by hybridization to pSp102, containing three-quarters of the SUEHGR sequences. The absolute levels of ubiquitination were estimated as described in Materials and Methods. The increased enrichment at $10 \mathrm{~h}$ was almost exactly compensated by the increased average level of ubiquitination at $36 \mathrm{~h}$, such that SUEHGR did not have a significantly increased level of ubiquitination when transcriptionally active. The assumptions of this analysis, although reasonable, cannot be experimentally tested without direct isolation of active SUEHGR as chromatin, which has proved very difficult [Vincenz et al., 1991].

We also analyzed ubiquitination of the spacer, pro- 
TABLE 1. Representation and Level of Ubiquitination of H2A and H2B Variants From Two Stages of Sea Urchin Development

\begin{tabular}{|c|c|c|c|c|c|c|}
\hline \multirow[b]{2}{*}{ Variant } & \multicolumn{3}{|c|}{$10 \mathrm{~h}$} & \multicolumn{3}{|c|}{$36 \mathrm{~h}$} \\
\hline & $\begin{array}{c}\text { Representation } \\
\text { of variant }(\%)\end{array}$ & $\begin{array}{l}\text { Ubiquitination } \\
\text { of variant }(\%)\end{array}$ & $\begin{array}{c}\text { Average } \\
\text { ubiquitination } \\
\text { of } \mathrm{H} 2 \mathrm{~A} \text { or } \mathrm{H} 2 \mathrm{~B}(\%)\end{array}$ & $\begin{array}{c}\text { Representation } \\
\text { of variant }(\%)\end{array}$ & $\begin{array}{l}\text { Ubiquitination } \\
\text { of variant }(\%)\end{array}$ & $\begin{array}{c}\text { Average } \\
\text { ubiquitination } \\
\text { of } \mathrm{H} 2 \mathrm{~A} \text { or } \mathrm{H} 2 \mathrm{~B}(\%)\end{array}$ \\
\hline $\begin{array}{l}\mathrm{csH} 2 \mathrm{~A} \\
\mathrm{\alpha H} 2 \mathrm{~A} \\
\beta \mathrm{H} 2 \mathrm{~A} \\
\gamma \mathrm{H} 2 \mathrm{~A} \\
8 \mathrm{H} 2 \mathrm{~A} \\
\mathrm{H} 2 \mathrm{~A} . \mathrm{F} / \mathrm{Z}\end{array}$ & $\begin{array}{l}25 \\
69\end{array}$ & $\begin{array}{l}1.6 \\
1.1\end{array}$ & 1.2 & $\begin{array}{c}2.9 \\
46 \\
4 \\
35 \\
5.9 \\
6.7\end{array}$ & $\begin{array}{l}1.9 \\
2.2 \\
2.7 \\
0.6 \\
1.3 \\
2.0\end{array}$ & 1.6 \\
\hline $\begin{array}{l}\alpha \mathrm{H} 2 \mathrm{~B} \\
\beta, \gamma \mathrm{H} 2 \mathrm{~B}\end{array}$ & 100 & 0.7 & 0.7 & $\begin{array}{l}24 \\
76 \\
\end{array}$ & $\begin{array}{l}4.4 \\
1.5 \\
\end{array}$ & \} 2.1 \\
\hline
\end{tabular}
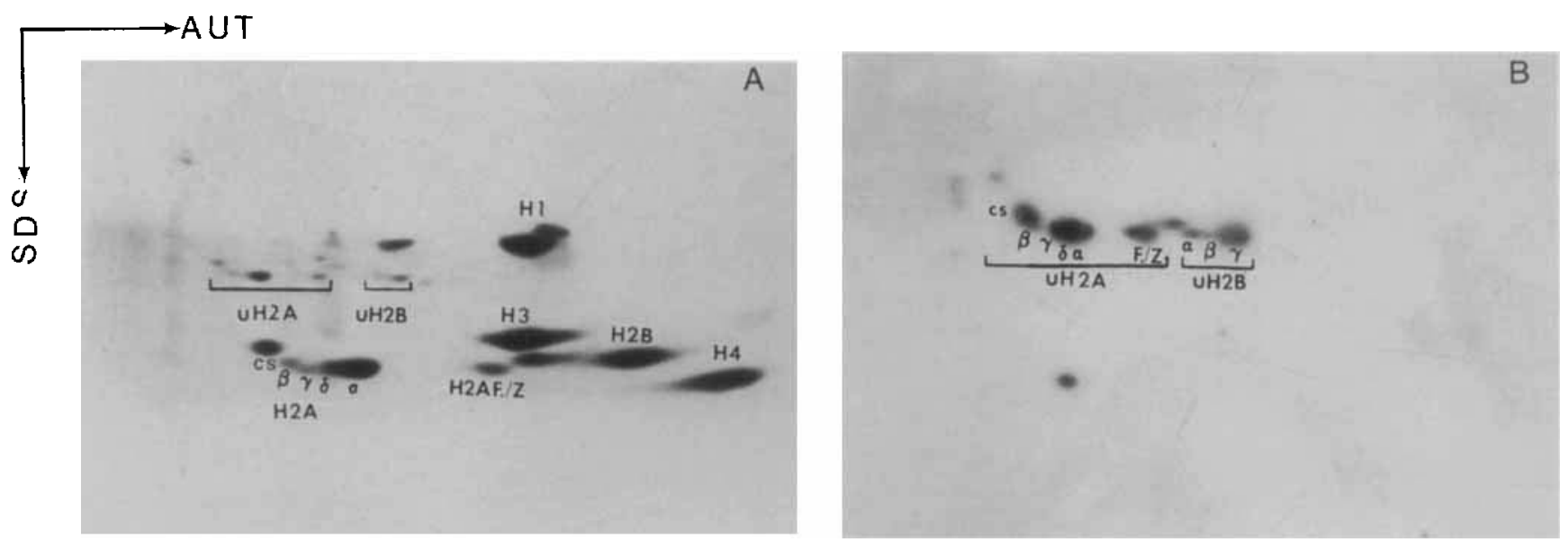

Fig. 3. Demonstration of specificity of antibodies in immunoblotting. 36-h Nuclear proteins were separated on a two-dimensional gel (AUT/SDS), blotted to nitrocellulose, and immunostained with antiubiquitin antibodies and ${ }^{125}$ I-protein A. A: Coomassie-stained gel. B: Autoradiogram of immunostained protein. Only monoubiquitinated histones were detectable.

moter, and coding regions at the early H3 locus. The results showed that immunoprecipitated complexes were not enriched in any of the regions at $36 \mathrm{~h}$ of embryogenesis. In contrast both the spacer and regulatory part were enriched about twofold and the coding region was enriched threefold at $10 \mathrm{~h}$. These experiments were reproduced with three different nuclear preparations. In agreement with the experiments with $\mathrm{pCO}_{2} \mathrm{~A}$ and pSp102, there was little evidence of significant hyperubiquitination at the $\mathrm{H} 3$ locus. Only a slightly higher level of ubiquitination was found in the regulatory region. The changes in apparent ubiquitination during repression of these genes were slight compared to the changes observed in individual histone variants between these same two stages in embryogenesis (Table 1 ).

The large sizes of the DNA fragments $(\sim 600 \mathrm{bp})$ and the probes $(\sim 300 \mathrm{bp})$ limit the resolution of these measurements. Therefore, the average level of ubiquitination of the regulatory region might be substantially greater than that indicated from our experiments.

\section{DISCUSSION \\ Monoubiquitinated Species Exist for All Variants of Sea Urchin Histones H2A and H2B}

Analysis of two-dimensional gels of labeled nuclear proteins revealed monoubiquitinated species of each of the H2A and $\mathrm{H} 2 \mathrm{~B}$ variants throughout embryonic development. It is interesting that $\mathrm{H} 2 \mathrm{AF}$. $\mathrm{Z}$ was also ubiquitinated, because although it contains a characteristic $\mathrm{H} 2 \mathrm{~A}$ core, its sequence is only $57 \%$ homologous with other $\mathrm{H} 2 \mathrm{~A}$ variants, and it is expressed throughout the cell cycle as a polyadenylated message [Ernst et $a l ., 1987]$. It is significant that polyubiquitinated histones were not detected. Polyubiquitination of histones was demonstrated in trout liver [Davie et al., 1987], human breast cancer cells [Davie and Murphy, 1990], bovine thymus, chicken erythrocytes, and Tetrahymena macro- and micronuclei [Nickel et al., 1989]. We could not detect such highly modified histone species by Coomassie staining, radioactivity, or immunostaining. Most likely, this histone modification is not uti- 


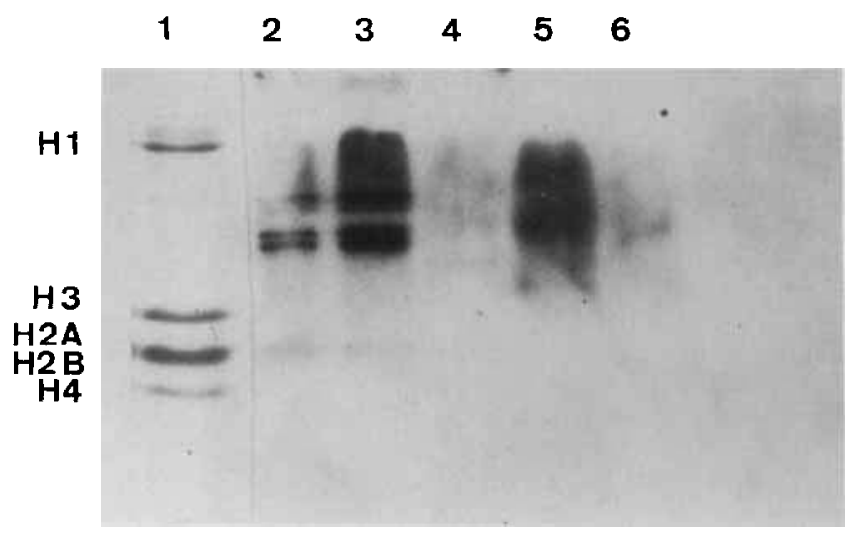

Fig. 4. SDS-PAGE analysis of immunoprecipitated proteins from 10-h embryo chromatin. Lane 1: Control of Coomassie-stained acidextracted total nuclear proteins from $10 \mu \mathrm{g}$ chromatin. Lanes 2-6: Immunoblot immunostained with antiubiquitin antibodies and ${ }^{125} \mathrm{I}$ protein A. Lanes, 2,3: Acid-extracted total nuclear proteins from 10 $\mu \mathrm{g}$ and $20 \mu \mathrm{g}$ chromatin. Lanes 4-6: Proteins from 80, 135, and 250 ng of immunoprecipitated chromatin, originating from nuclei crosslinked for 3,10 , and $30 \mathrm{~min}$, respectively. Lanes containing proteins from $10 \mu \mathrm{g}$ of chromatin from the immunoreaction supernatants showed no detectable reaction with antiubiquitin, showing that the immunoreaction was $>95 \%$ efficient for immunoreactive histones.

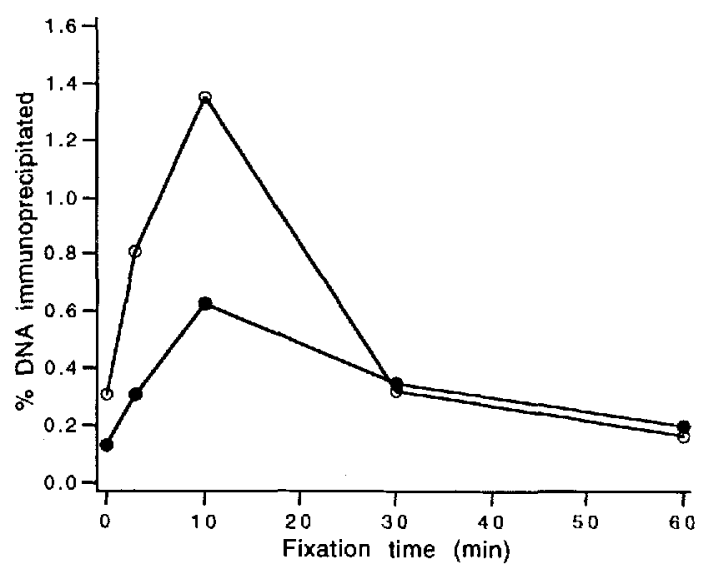

Fig. 5. Dependence of chromatin precipitation upon fixation time. Ten-hour nuclei $(O)$ and $36-\mathrm{h}$ nuclei $(\$)$ were immunoprecipitated with antiubiquitin antibodies after different fixation times. DNA was quantitated by $\left[{ }^{3} \mathrm{H}\right]$ thymidine radioactivity.

lized in the early sea urchin development stages, or polyubiquitinated histones are present in levels too low for us to detect $(<0.03 \%$ of non-ubiquitinated species).

\section{Histone Variants Are Differentially Ubiquitinated in a Stage-Specific Fashion}

In sea urchin embryos the different variants are ubiquitinated to different extents (Table 1). For instance, at $36 \mathrm{~h} \beta \mathrm{H} 2 \mathrm{~A}$ was almost five times more ubiquitinated than $\gamma \mathrm{H} 2 \mathrm{~A}$. There seems to be a slight correlation between the order of synthesis of the variants and their level of ubiquitination. At $36 \mathrm{~h}$ the early

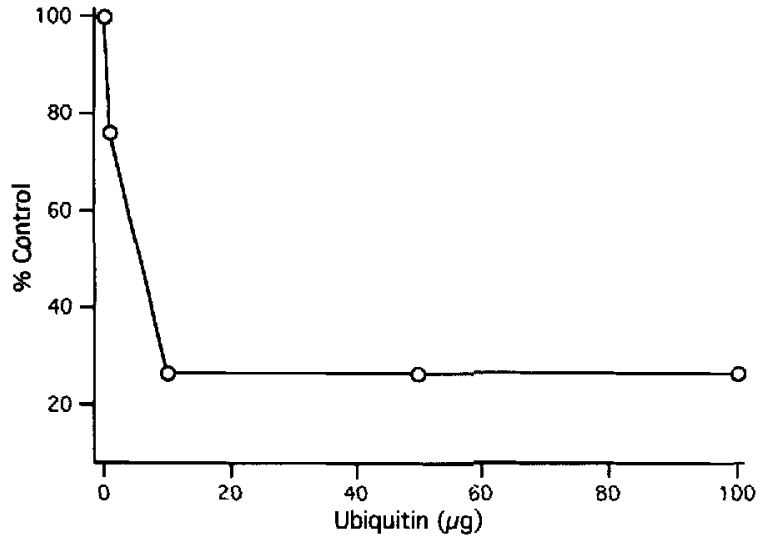

Fig. 6. Immunoprecipitation competition with ubiquitin. Increasing quantities of ubiquitin were added to the fixed $10-\mathrm{h}$ chromatin samples before immunoprecipitation with the antiubiquitin antibodies. The quantities of immunoprecipitated $\left[{ }^{3} \mathrm{H}\right]$ thymidine-labeled chromatin were determined by scintillation counting. Values on the ordinate represent amount of immunoprecipitated complexes expressed as a percentage of controls performed without competitor. Nonimmune serum resulted in precipitation about $15 \%$ of total immunoprecipitated chromatin.

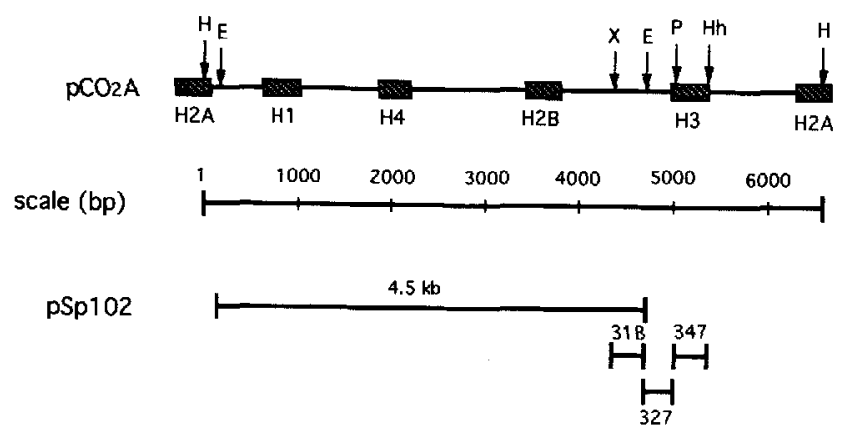

Fig. 7. SUEHGR gene and hybridization probes used. The black boxes are coding regions for each gene. The arrows point to the restriction enzyme cleavage sites. Restriction enzymes are abbreviated as follows: H, HindIII; E, EcoRI; X, XbaI; P, PvuII; Hh, HhaI.

variants are slightly more ubiquitinated. Ubiquitination cannot be controlled exclusively by the primary amino acid structure, because of the dramatic differences in ubiquitination that seem correlated with developmental stage. Although csH2A was ubiquitinated to the same extent at both $10 \mathrm{~h}$ and $36 \mathrm{~h}, \alpha \mathrm{H} 2 \mathrm{~A}$ and $\alpha \mathrm{H} 2 \mathrm{~B}$ were twofold and 6.4-fold more ubiquitinated at $36 \mathrm{~h} . \alpha \mathrm{H} 2 \mathrm{~B}$ was the least ubiquitinated species at $10 \mathrm{~h}$, but the most highly modified at $36 \mathrm{~h}$. Differences in ubiquitination could be the result of stage-dependent differences in variant conformation or function or of differences in the ubiquitination system.

\section{Active Early Histone Gene Chromatin Does Not Seem To Be Hyperubiquitinated}

Using immunoprecipitation we investigated the ubiquitination of proteins fixed to the early histone 

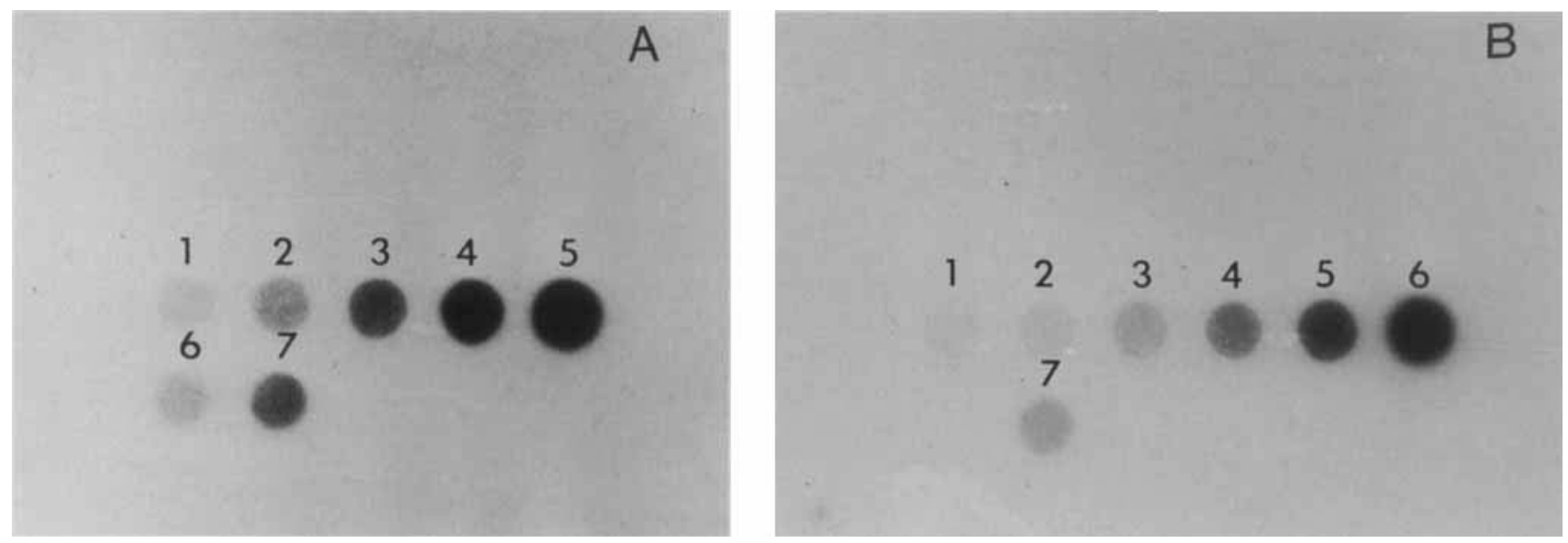

Fig. 8. An example of dot-blot hybridization of total and immunoprecipitated DNA, using pSp 102. A: Ten-hour embryos. Dots 1, 2, 3, 4,5 contain 25,50,100, 200, and $400 \mathrm{ng}$ of total DNA, respectively. Dots 6,7 contain 10 and 25 ng immunoprecipitated DNA, respectively. B: Thirty-six-hour embryos. Dots 1, 2, $3,4,5,6$ contain $25,50,100,200,400$, and $600 \mathrm{ng}$ of total DNA, respectively. Dot 7 contains $50 \mathrm{ng}$ immunoprecipitated DNA.

TABLE 2. Immunoprecipitation of Early Histone Gene DNA From 10-h and 36-h Embryos

\begin{tabular}{lccccc}
\hline Probes & $E(s, 10)^{\mathrm{a}}$ & $E(s, 36)^{\mathrm{a}}$ & $f_{u}(s, 10)^{\mathrm{h}}$ & $f_{u}(s, 36)^{\mathrm{b}}$ & $f_{u}(s, 10) / f_{u}(s, 36)^{\mathrm{c}}$ \\
\hline pCO2A & 4.6 & 2.2 & 0.044 & 0.041 & 1.1 \\
pSp102 & 4.0 & 2.3 & 0.038 & 0.043 & 0.9 \\
Regulatory region & 3.1 & 1.1 & 0.029 & 0.020 & 1.5 \\
Structural region & 2.3 & 0.9 & 0.022 & 0.017 & 1.3 \\
Spacer region & 1.6 & 0.8 & 0.015 & 0.015 & 1.0 \\
\hline
\end{tabular}

${ }^{\mathrm{a}} E(s, t)$ is the enrichment of specific sequence DNA in the immunoprecipitates from embryos 10 or $36 \mathrm{~h}$ old.

${ }^{\mathrm{b}} \mathrm{f}_{u}(s, t)$ is the estimated absolute level of histone H2A and H2B ubiquitination using average values for $f_{u}(b, 10)=0.0095$ and $f_{u}(b, 36)=0.0185$ from Table 1 .

${ }^{\mathrm{c}} f_{u}(s, 10) / f_{u}(s, 36)$ is the relative ubiquitination of the active and inactive histone genes.

genes. We confirmed the antibody specificities using Western blots, SDS/PAGE of the immunoprecipitated complexes, and competition experiment with free ubiquitin. Competition with ubiquitin reduced the amount of $10 \mathrm{~h}$ SUEHGR chromatin precipitated by the same factor as the precipitation of bulk chromatin was reduced (Fig. 4). Thus, we expected the same high specificity of the immunoprecipitation of SUEHGR nucleoprotein that was achieved with bulk chromatin. Active $10 \mathrm{~h}$ SUEHGR chromatin was enriched more than fourfold compared to bulk chromatin at the same stage; however, a quantitative estimate of the absolute level of ubiquitination showed little if any additional ubiquitination when the genes were active. Thus, these results agree with other studies indicating that active genes are more highly ubiquitinated than bulk chromatin in the same cells [Levinger and Varshavsky, 1982; Barsoum and Varshavsky, 1985; Ridsdale and Davie, 1987; Nickel et al., 1989; Davie and Murphy, 1990]. In the early histone genes, this difference persists after the genes are silenced. The most surprising result is that the absolute levels of ubiquitination of the early histone genes do not seem to change as the genes were silenced, even though the chromatin has undergone a dramatic change in structure [Bryan et al., 1983; Wu and Simpson, 1985; Fronk et al., 1990]. Earlier studies have not addressed the question of whether the relative or absolute levels of ubiquitination might be more significant for histone function.

It is indeed possible that early histone genes are regulated without changes in absolute level of ubiquitination. The use of ubiquitination for gene regulation might be different for different organisms or for expression of different genes. For example, yeast is able to grow normally in the complete absence of ubiquitination of H2A [Swerdlow et al., 1990].

Four assumptions were made to calculate the absolute levels of ubiquitination (see Materials and Methods). First, specific and non-specific DNA fragments in an immunoprecipitation were assumed to have the same molecular weight, which is reasonable, because the sonication was carried out on solubilized nucleoprotein. Second, the nucleosome repeat length and histone stoichiometry were assumed to be the same in active 
and inactive genes. Active genes are known to have disrupted nucleosome ladders, but with similar nucleosome densities as found on inactive genes, as assayed by micrococcal nuclease digestion, sedimentation analysis, and psoralen crosslinking [Wu et al., 1979; Caplan et al., 1987; Cavelli and Thoma, 1993]. Some evidence seems to indicate that the active nucleosomes are sometimes packed more tightly than inactive nucleosomes [Villeponteau et $a l ., 1992$ ]. It is also unlikely that the levels of $\mathrm{H} 2 \mathrm{~A}$ and $\mathrm{H} 2 \mathrm{~B}$ are different in active and inactive chromatin, because nucleoproteins gels show that although some of the active nucleosome core particles migrate more slowly than bulk nucleosomes, the majority of the active core particles comigrate with bulk nucleosomes. If the active core particles were depleted in H2A or H2B they would have increased charge and therefore should migrate faster than bulk chromatin. Third, we assumed that ubiquitinated histones from active and inactive early histone genes would be fixed to DNA with the same efficiency. This assumption cannot be tested, but it is most likely that ubiquitinated histones bind in the same fashion to active and inactive genes. Fourth, it was assumed that the efficiency of precipitation of fixed ubiquitinated proteins from active and inactive genes was the same, which is reasonable, based on the fact that the proteins were denatured prior to immunoprecipitation, the immunoprecipitation of bulk ubiquitinated histones was very efficient $(>95 \%)$, and free ubiquitin competed equally well with precipitation of active SUEHGR genes and bulk DNA. Even though we have made the most reasonable assumptions for our analysis of ubiquitination of active genes, many of the assumptions cannot be experimentally validated. For instance, it is possible that ubiquitinated histones on active genes are crosslinked to DNA with lower efficiency than ubiquitinated histones bound to inactive genes. Unfortunately all studies of ubiquitination are subject to uncertainties in the fixation or exchange of histones on active and inactive genes.

It is also possible that only the regulatory regions of active genes are hyperubiquitinated. In this case, our experiments would tend to underestimate the extent of ubiquitination, because of the large size of the sonicated DNA. For instance, a ubiquitinated histone located at the $5^{\prime}$ end of the coding region could have become crosslinked to DNA molecules with sequences located as much as \pm 600 bp upstream or downstream. Because the probe molecules are about $300 \mathrm{bp}$ long, it would be possible to precipitate such fragments with probes centered as much as $750 \mathrm{bp}$ from the $5^{\prime}$ end of the gene. Thus the resolution and sensitivity of the immunoprecipitation technique is limited by the difficulty in shearing DNA to less than $600 \mathrm{bp}$ in length. In principle the resolution could be increased by treatment of the sonicated DNA with an endonuclease, and by using oligonucleotide probes.

It is also possible that earlier experiments correlat- ing gene activity with ubiquitination have been misinterpreted. The facts that bulk histones are hypoubiquitinated in Tetrahymena micronuclei [Davie et al., 1991] and in mitotic cells [Matsui, 1975] might be correlated with physical compaction, for instance, and unrelated to transcriptional inactivity. Varshavsky's conclusions that active nucleosome core particles contain hyperubiquitinated histones have been challenged by Huang et al. [1986], who found that although nucleosome core particles from active genes comigrated with ubiquitinated core particles, the migration was not altered by deubiquitination, showing that the active nucleosomes were not ubiquitinated. Davie's conclusions about ubiquitination were based on highly soluble chromatin being enriched both in ubiquitinated histones and in transcribed sequences. However, it is possible that chromatin solubility is due to multiple, independent factors.

Our results showed differential ubiquitination at different sites in the early H3 locus. At $36 \mathrm{~h}$, when the gene was inactive, the spacer, regulatory region, and coding sequences were all ubiquitinated to the same level as bulk chromatin. In contrast, at $10 \mathrm{~h}$, when the gene was active, the regulatory region was immunoprecipitated twice as efficiently as the $5^{\prime}$ spacer region. Such results show the power of the technique to distinguish between different regions of the same chromatin domain.

\section{ACKNOWLEDGMENTS}

We thank Dr. Claudius Vincenz for his critical reading and helpful discussions, J.R. Davie for antiubiquitin antibodies, E. Weinberg for pCO2A, and L. Kedes for pSp102. This work was supported by NIH GM44403 and NSF DCB9007295.

\section{REFERENCES}

Allis CD, Glover CVC, Bowen JK, Gorovsky MA (1980): Histone variants specific to the transcriptionally active, amitotically dividing macronucleus of the unicellular eucaryote, Tetrachymena thermophila. Cell 20:609-617.

Arceci RJ, Gross PR (1980): Histone variants and chromatin structure during sea urchin development. Dev Biol 80:186-209.

Barsoum J, Varshavsky A (1985): Preferential localization of variant nucleosomes near the 5 '-end of the mouse dihydrofolate reductase gene. J Biol Chem 260:7688-7697.

Bryan PN, Olah J, Birnstiel ML (1983): Major changes in the $5^{\prime}$ and 3 ' chromatin structure of sea urchin histone genes accompany their activation and inactivation in development. Cell 33:843-848.

Busch H, Goldknopf IL (1981): Uhiquitin-protein conjugates. Mol Cell Biol 40:173-187.

Caplan A, Kimura T, Gould H, Allan J (1987): Perturbation of chromatin structure in the region of the adult beta-globin gene in chicken erythrocyte chromatin. J Mol Biol 193:57-70.

Cavelli G, Thoma F (1993): Chromatin transitions during activation and repression of galactose-regulated genes in yeast. EMBO J 12: $4603-4613$.

Childs G, Maxson R, Kedes LH (1979): Histone gene expression during sea urchin embryogenesis: isolation and characterization of early and late messenger RNAs of Strongylocentrotus purpuratus by gene-specific hybridization and template activity. Dev Biol 73: $153-173$. 
Cohen LH, Mahowald AP, Chalkley R, Zweidler A (1973): Histone of early embryos. Fed Proc 32:588.

Cohen LH, Newrock KM, Zweidler A (1975): Stage-specific switches in histone synthesis during embryogenesis of the sea urchin. Science 190:994-997.

Davie JR, Murphy LC (1990): Level of ubiquitinated histone H2B in chromatin is coupled to ongoing transcription. Biochemistry 29: $4752-4757$.

Davie JR, Delcuve GP, Nickel BE, Moirier R, Bailey G (1987): Reduced levels of histones $\mathrm{H} 1^{\circ}$ and $\mathrm{H} 1 \mathrm{~b}$, and unaltered content of methylated DNA in rainbow trout hepatocellular carcinoma chromatin. Cancer Res 47:5407-5410.

Davie JR, Lin R, Allis CD (1991): Timing of the appearance of ubiquitinated histones in developing new macronuclei of Tetrachymena thermophila. Biochem Cell Biol 69:66-71.

Delcuve GP, Davie JR (1992): Western blotting and immunochemical detection of histones electrophoretically resolved on acid-urea-triton and sodium dodecyl sulfate-polyacrylamide gels. Anal Biochem 200:339-342.

Dedon PC, Soults JA, Allis CD, Gorovsky MA (1991): A simplified formaldehyde fixation and immunoprecipitation technique for studying protein-DNA interactions. Anal Biochem 197:83-90.

Ernst SG, Miller H, Brenner CA, Nocente-McGrath C, Francis S, MeIsaac R (1987): Characterization of a cDNA clone coding for a sea urchin histone H2A variant related to the H2A.F/Z histone protein in vertebrates. Nucleic Acids Res 15:4629-4644.

Finley D, Chau V (1991): Ubiquitination. Annu Rev Cell Biol 7:25-69.

Franklin SG, Zweidler A (1977): Non-allelic variants of histones 2a, 2b and 3 in mammals. Nature 266:273-275.

Fronk J, Tank GA, and Langmore P (1990): Chromatin structure of the developmentally regulated early histone genes of the sea urchin Strongylocentrotus purpuratus. Nucleic Acids Res 18:5255-5263.

Goldknopt IL, Busch H (1977): Isopeptide linkage between nonhistone and histone $\mathrm{H} 2 \mathrm{~A}$ polypeptides of chromosomal conjugate-protein A24. Proc Natl Acad Sci USA 74:864-868.

Grunstein M (1990): Histone function in transcription. Annu Rev Cell Biol 6:643-678.

Hershko A (1988): Ubiquitin-mediated protein degradation. J Biol Chem 263:15237-15240.

Hershko A (1991): The ubiquitin pathway for protein degradation. TIBS 16:265-268.

Huang S-Y, Barnard MB, Xu M, Matsui S, Rose SM, Garrard W'T (1986): The active immunoglobulin $\kappa$ chain is packaged by nonubiquitin-conjugated nucleosomes. Biochemistry 83:3738-3742.

Jentsch S, Seufert W, Sommer T, Reins H-A (1990): Ubiquitin-conjugating enzymes: novel regulators of eukaryotic cells. TIBS 15:195198.

Johnson ES, Bartel B, Seufert W, Varshavsky A (1992a): Ubiquitin as a degradation signal. EMBO J 11:497-505.

Johnson LM, Fisher-Adams G, Grunstein M (1992b): Identification of a non-basic domain in the histone $\mathrm{H} 4 \mathrm{~N}$-terminus required for repression of the yeast silent mating loci. EMBO J 11:2201-2209.

Kleinschmidt AM, Martinson HG (1981): Structure of nucleosome core particles containing uH2A. Nucleic Acid Res 9:2423-2431.

Laemmli UK (1970): Cleavage of structural proteins during the assembly of the head of bacteriophage T4. Nature 227:680-685.

Levinger L, Varshavsky A (1982): Selective arrangement of ubiquitinated and D1 protein-containing nucleosomes within the Drosophila genome. Cell 28:375-385.

Lieber T, Weisser K, Childs G (1986): Analysis of histone gene expression in adult tissues of the sea urchins Strongylocentrotus purpuratus and Lytechinus pictus: tissue-specific expression of sperm histone genes. Mol Cell Biol 6:2602-2612.

Mann RK, Grunstein M (1992): Histone H3 N-terminal mutations allow hyperactivation of the yeast GAL1 gene in vivo. EMBO J 11:3297-3306.

Matsui S, Seon BK, Sandberg AA (1979): Disappearance of a structural chromatin protein A24 in mitosis: implications for molecular basis of chromatin condensation. Proc Natl Acad Sci USA 76:63866390 .
Maxson RE, Wilt FH (1981): The rate of synthesis of histone mRNA during the development of sea urchin embryos (Strongylocentrotus purpuratus). Develop Biol 83:380-386.

McGrath JP, Jentsh S, Varshavsky A (1991): UBA1: an essential yeast gene encoding ubiquitin-activating enzyme. EMBO J 10:227236.

Mueller RD, Yasuda H, Hatch CL, Bonner WM, Bradbury EM (1985): Identification of ubiquitinated histones $2 \mathrm{~A}$ and $2 \mathrm{~B}$ in Physarum polycephalum. J Biol Chem 260:5147-5153.

Newrock KM, Alfageme CR, Nardi RV, Cohen LH (1977); Histone changes during chromatin remodeling in embryogenesis. Cold Spring Harbor Symp Quant Biol 1:421-431.

Newrock KM, Cohen KH, Hendricks MB, Donnelly RJ, Weinberg ES (1978): Stage-specific mRNAs coding for subtypes of H2A and H2B histones in the sea urchin embryo. Cell 14:327-336.

Nickel BE, Allis CD, Davie JR (1989): Ubiquitinated histone H2B is preferentially located in transcriptionally active chromatin. Biochemistry $28: 958-963$

Nickel BE, Davie JR (1989): Structure of polyubiquitinated histone H2A. Biochemistry 28:964-968.

Nickel BE, Roth SY, Cook RG, Allis CD, Davie JR (1987): Changes in the histone $\mathrm{H} 2 \mathrm{~A}$ variant $\mathrm{H} 2 \mathrm{~A} . \mathrm{Z}$ and polyubiquitinated histone species in developing trout testis. Biochemistry 26:4417-4421.

Overton GC, Weinberg ES (1978): Length and sequence heterogeneity of the histone gene repeat unit of the sea urchin, S. purpuratus. Cell $14: 247-257$.

Panyim S, Chalkley R (1969): The heterogeneity of histones. I. A quantitative analysis of calf histones in very long polyacrylamide gels. Biochemistry 8:3972-3979.

Pehrson JR, Cohen LH (1985): Distribution of histone H1a among cells of the sea urchin embryo. Develop Biol 111:530-533.

Poccia DL, Hinegardner RT (1975): Developmental changes in chromatin proteins of the sea urchin from blastula to mature larva. Develop Biol 45:81-89.

Ridsdale JA, Davie JR (1987): Chicken erythrocyte polynucleosomes which are soluble at physiological ionic strength and contain linker histones are highly enriched in $\beta$-globin gene sequences. Nucl Acids Res 15:1081-1096.

Roth SY, Shimizu M, Johnson L, Grunstein M, Simpson RT (1992): Stable nucleosome positioning and complete repression by the yeast alpha 2 repressor are disrupted by amino-terminal mutations in histone H4. Genes Dev 6:411-425.

Schwager S, Retief JD, de Groot P, von Holt C (1985): Rapid exchange of histones H2A and H2B in sea urchin embryo chromatin. FEBS LETTERS 189:305-309.

Simpson RT (1990): Nucleosome positioning can affect the function of a cis-acting DNA element in vivo. Nature 343:387-389.

Solomon MJ, Larsen PL, Varshavsky A (1988): Mapping protein-DNA interactions in vivo with formaldehyde: Evidence that histone $\mathrm{H} 4$ is retained on a highly transcribed gene. Cell 53:937-947.

Swerdlow PS, Finley D, Varshavsky A (1986): Enhancement of immunoblot sensitivity by heating of hydrated filters. Anal Biochem 156:147-153.

Swerdlow PS, Schuster T, Finley D (1990): A conserved sequence in histone $\mathrm{H} 2 \mathrm{~A}$ which is a ubiquitination site in higher eukaryotes is not required for growth in Saccharomyces cerevisiae. Mol Cell Biol 10:4905-4911.

Thorne AW, Sautiere P, Briand G, Crane-Robinson C (1987): The structure of ubiquitinated histone H2B. EMBO J 6:1005-1010.

Van Daal A, Elgin SCR (1992): A histone variant, H2AvD, is essential in Drosophila melanogaster. Mol Cell Biol 3:593-602.

Van Holde KE (1989): Springer Series in Molecular Biology. In Rich A (ed): "Chromatin." New York: Springer-Verlag.

Villeponteau B, Brawley J, Martinson HG (1992): Nucleosome spacing is compressed in active chromatin domains of chick erythroid cells. Biochemistry 31:1554-1563.

Vincenz C, Fronk J, Tank GA, Langmore JP (1991): Nucleoprotein hybridization: a method for isolating active and inactive genes as chromatin. Nucleic Acids Res 19:1325-1335.

Weinberg ES, Hendricks MB, Hemminki K, Kuwabara PE, Farrelly 
LA (1983): Timing and rates of synthesis of early histone mRNA in the embryo of Strongylocentrotus purpuratus. Dev Biol 98:117129 .

West MHP, Bonner WM (1980): Histone 2A, a heteromorphous family of eight protein species. Biochemistry 19:3238-3245.

Wu TC, Simpson RT (1985): Transient alterations of the chromatin structure of sea urchin early histone genes during embryogenesis. Nucleic Acids Res 13:6185-6203.

Wu C, Wong YC, Elgin SC (1979): The chromatin structure of specific genes: II. Disruption of chromatin structure during gene activity. Cell 16:807-814.

Wu RS, Kohn KW, Bonner WM (1981): Metabolism of ubiquitinated histones. J Biol Chem 256:5916-5920.

Wu RS, Panusz HT, Hatch CL, Bonner WM (1986): Histones and their modifications. CRC Crit Rev Biochem 20:201-263.

Zweidler A (1978): Resolution of histones by polyacrylamide gel electrophoresis in presence of nonionic detergents. Methods Cell Biol $17: 223-233$ 